\title{
Changes in Estonian Defense Policy Following EPISODES OF RUSSIAN AgGression
}

\section{BenJAMin CoOper ${ }^{\mathrm{I}}$}

\section{Abstract}

After successive episodes of Russian aggression, both Estonia and the North Atlantic Treaty Organization (NATO) remain on edge about the future of their relationship with Moscow. To understand how Estonia has deterred Russia from further hostile acts, this paper analyzes the Estonian government's response to them and how the establishment of defense programs have made Estonia a pillar of anti-Russian policy in Europe. Such programs and policy changes which continue to deter Russia from these aggressive tactics include but are not limited to NATO's Cooperative Cyber Defense Center of Excellence, the EU's East StratCom Task Force, and the development of dependable relationships between $\mathrm{NATO}$, the EU, and the Estonian private defense sector. The paper also analyzes the overall successes and deficiencies of these policy changes, makes future recommendations for the Estonian government, and evaluates the implications of these changes in the broad realm of international security. Analyzing these successes and deficiencies is important for determining the overall effectiveness of the changes in Estonian policy over the past decade. Through in-person interviews with both American and Estonian government officials, online research, and interactions with academic experts on the subject, the paper argues these new programs and evolving relationships are an adequate and effective deterrent to prevent further Russian cyber and conventional military attacks.

\footnotetext{
1 Benjamin Cooper is a junior at Tufts University from Los Angeles, California. He is majoring in International Relations and minoring in Entrepreneurial Leadership Studies. Benjamin is a member of two consulting groups at Tufts and also manages the Tufts Football team. Outside of the classroom, he enjoys traveling to new places, hiking in Yosemite National Park, and spending time with his family and friends.
} 


\section{INTRODUCTION}

Since the fall of the Soviet Union in December of 1991, Estonia and the Baltic States have been in a precarious position of balancing between Russia and the Western alliances of NATO and the EU. In the past decade, acts of Russian aggression toward the West have not only become more frequent but also significantly more impactful and dangerous. Specifically, in 2007, Russia targeted Estonia in a series of cyberattacks over the movement of the Bronze Horseman statue. How and why has Estonia responded to the 2007 attacks and each successive bout of Russian aggression since? In contrast to countries like Germany, who have chosen to remain closer with Russia due to its energy resources, Estonia has taken a hardline stance on the issue.

This paper argues that the government of Estonia has solidified its relationship with NATO, the EU, and the private defense sector in response to three events: the 2007 Bronze Horseman incident in Tallinn, the 2008 RussoGeorgian war, and the 2014 seizure of Crimea. In the process, Estonia has set an example for other states threatened by Russia on how to fight against the Kremlin. Each section of the paper breaks down Estonia's relationship with one of the entities listed above (i.e. NATO, EU, or private defense sector). Within each section, the paper analyzes the state of the current relationship with the entity, systemic and practical security policy changes within the entity in response to Russian aggression, obstacles to successfully implement those policy changes, and overall successes and failures of the policy changes and the government-entity relationships. These metrics best determine how Estonia has responded to Russian aggression because they provide a holistic understanding of the relationships between the Estonian government and the entities that support their fight. The Estonian government's relationships with its defense apparatus, NATO, the EU, and the Estonian private sector each have unique and consequent implications and, as a result, must be analyzed separately in order to fully understand Estonia's response to what it deems to be unacceptable acts of aggression.

\section{WHY ESTONIA?}

Estonia's importance as an actor on the geopolitical stage cannot be understated. It is one of only three NATO member countries that share a border with Russia proper. As a result, Tallinn must worry about Russian troops on its border and a potential invasion.

Estonia is unique in the Western-aligned European world in regard to its 
ethnic makeup. The Estonian government focuses most of its efforts on keeping the peace between the Russian and Estonian ethnic groups in Harju (55\% of the ethnic Russian population) and Ida Viru (32\% of the ethnic Russian population) counties. $^{2}$ The ethnic Russian population in the remaining counties of Estonia represent $5 \%$ or less of the population of the county itself. These ethnic Russians are a significant political and economic faction of the population which must be analyzed to help avoid future ethnic conflict.

While relations between ethnic Estonians ${ }^{3}$ and ethnic Russians ${ }^{4}$ are calm, there are significant socioeconomic differences between the two groups which the Estonian government must monitor. ${ }^{5}$ These socioeconomic differences are compounded by the differing media consumption by the ethnic Russians and ethnic Estonians. The easternmost county of Ida Viru is $72.8 \%$ ethnic Russian, and these ethnic Russians receive most of their news from Russian language news outlets controlled by the Kremlin. ${ }^{6}$ As a result, just $27 \%$ of Russianspeaking Estonian citizens support the NATO presence in the region. ${ }^{7}$ These socioeconomic differences must be noted. If they are not, Russian propaganda and disinformation campaigns can take advantage of the divide and create a divisive population.

Furthermore, Estonia's population size makes the country a prime target for an experienced and modern military force such as that of Russia. Its small population of 1.3 million people impacts the government's decision-making when it comes to future investments, tangible military strategy, and the setting of development goals in Estonia's Long-Term Development Plans released by the government each decade. ${ }^{8}$

While many cities in Estonia are densely populated, the countryside is sparsely inhabited and consists mostly of flat marsh. The abundance of marshland

\footnotetext{
2 "Population By Sex, Ethnic Nationality And County, 1 January." Statistics Estonia 2018.

3 Estonian citizens of Estonian descent

4 People of Russian descent who are citizens of Estonia or are stateless people but are not citizens of the Russian Federation

5 Martin Herem (Major General of the Estonian Army), in-person interview, June 11, 2018.

6 "Population By Sex, Ethnic Nationality And County, 1 January." Statistics Estonia 2018.

7 Dario Cavegn, "Majority of Estonia's Russian-speaking residents against NATO presence" last modified June 10, 2017. Estonia Public Broadcasting. https://news.err.ee/601288/majorityof-estonia-s-russian-speaking-residents-against-nato-presence

8 “Estonia Population 2018," World Population Review, last modified June 12, 2018, http:// worldpopulationreview.com/countries/estonia-population/.
} 
makes invasion a tough task but also represents a difficult barrier to building adequate and substantive defensive measures. The flatness of the country ensures that invaders face few physical barriers; therefore, an advancing Russian military force would find little resistance as it moved through the countryside.

Overall, Estonia's combination of a small population size, open terrain, and ethnic Russian minority makes it a critical liability amongst the NATO alliance. Russia has also demonstrated in Crimea what a hybrid invasion with a minority ethnic group acting as a catalyst would look like. Estonian Major General Martin Herem indicated in his interview that he has little doubt Russia sees Estonia as a land grab opportunity and would act on its instincts if it were not for the relationships Estonia has built with NATO.? While the Estonian government is confident that the economic and political success of Estonia keeps ethnic Russians devoted to Tallinn, they are aware of the ties that many ethnic Russians have to Moscow. Because of this dichotomy and the unique ethnic makeup and demographics of Estonia, the country represents an important case study in how the NATO alliance and the West are standing up to an increasingly aggressive Russia.

\section{Estonian Defense Forces (EDF)}

The Estonian Defense Forces, the first entity analyzed in this paper, are vital to the Estonian government because they are the first line of defense against any outside threat. More importantly, the EDF is the heart of the Estonian effort to defend against Russia. Without such a force, the Estonian government would have no capacity to defend against an outside incursion. The EDF provides land, sea, and air power to fight against any attack, and the force's strong presence in the Baltics gives confidence to Estonia's NATO allies that the country can be depended on in a time of war. Furthermore, the EDF acts as a uniting force amongst the Estonian population and helps mitigate any internal ethnic conflict which could arise in times of peace.

\section{OVERVIEW OF THE Role of THE EDF IN ESTONIAN DEFENSE SocIETY}

With the EDF acting as Estonia's first line of defense, its primary goals are the protection of Estonian sovereignty and the communal defense of the NATO alliance. The Estonian Ground Forces currently consist of about 3200 conscripts and 6000 active duty soldiers. ${ }^{10}$ The Ground Forces are reinforced by an extensive reserve unit and have participated in NATO combat activities in both Mali and

9 Maj. General Martin Herem, June 11, 2018.

10 Maj. General Martin Herem, June 11, 2018. 
Afghanistan, providing soldiers with combat and advanced weapon system skills they are unable to acquire in Estonia.

While the ground forces are Estonia's main fighting force, the Air Force and Navy provide important tactical support to the military, as well as essential infrastructure that could be utilized during a Russian invasion. Both Navy and Air Force missions remain vitally important to Estonia's defense against Russia, but they have not evolved as significantly as the Army's in response to Russian threats because of the immense cost to build and maintain effective weapons systems.

\section{EDF Security Goals: DeterRence and Collective Defense}

Deterrence and collective defense are at the heart of the Estonian government's policy to combat a Russian invasion. The Defense Forces understand the impracticality of launching an offensive attack and following acts of Russian aggression, the Estonian government has depended on and worked to develop even stronger relationships with its NATO allies. These relationships help deter Russia from invading and provide security to Estonia's population. As a result, and as outlined in the subsection below, the government is building up the EDF to compliment the weapons and training provided by NATO to ultimately possess a powerful military capability to deploy in defense against Russia.

NATO acts as the communal defense force for Estonia in case of invasion. According to Article $\mathrm{V},{ }^{11} \mathrm{NATO}$ considers an attack against one NATO state as an attack against the entire alliance, which plays an important role in Estonian military policy. The 2018 Siil Exercise brought together nineteen different countries and put Estonian military and Defense League forces on the battlefield with allied partner troops to increase cooperation and combat-readiness in the event of an attack. ${ }^{12}$ The Siil exercise and other cooperative military efforts, such as the Cooperative Cyber Defense Centre of Excellence (CCDCOE) in Tallinn, have demonstrated to the Russian government the advanced capabilities of an allied response against any aggressive action. The exercises also symbolize successful shifts in policy resulting in an

\footnotetext{
11 The collective defense clause laid out in the NATO treaty which states "an armed attack against one or more [of the NATO allies] shall be considered an attack against them all" 12 "Exercise Siil 2018 kicks off in Estonia," North Atlantic Treaty Organization, Last modified May 8, 2018, https:/www.nato.int/cps/su/natohq/news_154275.htm
} 
increase in deterrence and a more powerful response against a Russian threat.

\section{EVolution of EDF Policy in Response to Russian AgGRESSION}

Estonia was one of the first countries to have a well-rounded response to Russian aggression. Following the 2008 Georgian invasion, Estonia made an emphatic change in policy towards Russia from one of support and encouragement to one of opposition and open resistance. The policy changes listed below helped Estonia respond adequately to acts of Russian aggression.

The Estonian government regularly publishes documents explaining their long-term military development plans and strategy regarding Estonian National Security. The decisive change mentioned above is clearly presented in the difference in rhetoric in the National Security Concept document from 2004 and the one produced in 2010 after both the Bronze Horseman incident in 2007 and the invasion of Georgia in 2008. These documents are the foundation of Estonia's stance against Russian aggression, and their evolution signifies a broader shift of policy within the government as a whole. These documents also represent concrete guidelines to the Estonian population on how the government is combating this threat.

The Concept document of 2004 spoke of an effort by Estonia and its western alliances to cooperate with Russia and look for options to promote democracy in Moscow. There was less emphasis placed on building up NATO and Estonia's defenses and instead more on a need for defending "Europe's border."13 The rhetoric directed towards Russia changed sharply in the document from 2010, and NATO even discussed the potential for a military conflict. ${ }^{14}$ Even while President Obama called for a reset in Russian relations, Estonians were on the front line of Russian aggression and understood the seriousness of the Russian threat.

Beyond the National Security Concept document, Estonia also introduced the Long-Term Development Plan. Following the Georgian War in August of 2008, there was an extensive overhaul of the Long-Term Development Plan. The Plan, released in 2009 and set to finish in 2018, recognized the deficiencies within the Estonian system, sought to overhaul the communication and intelligence capabilities within the Estonian military, and made system and organizational compatibility

\footnotetext{
13 National Security Concept of the Republic of Estonia (2004). Date accessed July 9, 2018. https://www.files.ethz.ch/isn/156841/Estonia-2004.pdf

14 National Security Concept of the Republic of Estonia (2010). Date accessed July 9, 2018. https://www.eda.europa.eu/docs/default-source/documents/estonia---national-security-conceptof-estonia-2010.pdf
} 
with NATO and the Baltic States a priority. These policy changes helped ensure the future success of a NATO response to an attack on a member state such as Estonia. ${ }^{15}$

The Long-Term Development Plan also contained more practical and tangible upgrades than the broad, abstract statements and lack of professionalism that constituted Estonian military training policy before the Georgian war. ${ }^{16}$ Specific upgrades included replacing the older MILAN anti-tank system with the Javelin system anti-tank weapons and the development of high-alert readiness groups that could respond to any invasion at a moment's notice. ${ }^{17}$

Both of these documents are essential to understanding changes in Estonian military policy towards Russia because they provide insight into the mindset of the Estonian government officials creating the policy and how they viewed the Russian foreign ministry's goals. Furthermore, these documents lay out very specific action plans that the Estonian populous and outside analysts can use as evidence for or against the success of the response to Russian aggression.

\section{SUCCESSFUL IMPLEMENTATION OF ANTI-RUSSIAN POLICY IN THE EDF}

The Estonian Defense Forces have been successful in converting these policies into tangible results. This success is important because it shows progress in the government's plans and also proves to Estonia's NATO and EU allies that Estonia is serious in its efforts to combat Russian aggression. More specifically, the EDF ground forces have expanded the capabilities of their light infantry brigades through the adoption of Howitzer guns and participation in snap exercises to increase brigade readiness. ${ }^{18}$ Rather than investing in expensive twenty or thirty year development plans, Estonia focuses on improving the capabilities of their own army with training exercises and weapons systems that are reasonable and affordable. ${ }^{19}$ For example,

15 Estonian Long Term Defence Development Plan 2009-2018. January 22, 2009. http:// www.ecfr.eu/page/-/Estonie_-_2009_-_Estonia_long_term_development_plan_2009_2018. pdf

16 Maj. General Martin Herem, June 11, 2018.

17 Estonian Long Term Defence Development Plan 2009-2018. Date published January 22, 2009.

18 National Defence Development Plan 2018-2022. http://www.kaitseministeerium.ee/ riigikaitse2022/riigikaitse-arengukava/index-en.html

${ }_{19}$ Ingvar Pärnamäe (Estonian Defence Industry Association), in-person interview, June 8, 2018. 
the defense budget focuses primarily on increasing Defense League training, speeding up communications and transportation, increasing reaction speed and command capability, and maintaining barracks and armored personnel carriers. ${ }^{20}$ These improvements ensure NATO's advanced weapons systems and Estonia's well-trained defense forces will complement each other in the event of conflict.

Following Russia's annexation of Crimea in 2014, the Estonian government felt it was important to invest in the more advanced Javelin antitank weapon system. The Javelin missiles, an example of a strategic investment to maximize the government's return on investment, were funded by the U.S. Government through the European Reassurance Initiative set up by the Obama Administration to bolster NATO's defenses in Europe and demonstrated how Estonia uses its alliances and partnerships to their fullest potential. The Javelins are capable of attacking targets at distances of up to four kilometers and are a critical weapon system as Tallinn has no battle tanks in its armed forces. ${ }^{21}$

As a result of these policy changes and acquisition of new weapon systems, there has been a significant change in mindset of the soldiers in the Estonian military. While hard to prove in peacetime, Major General Herem described an Estonian military always prepared for war with Russia whether war is likely or not. He stated, "if you leave some to be taken, Russia will take it," and that following the conflicts in Georgia and Crimea, Estonian conscripts understand that war is a reality and are prepared to die in battle. ${ }^{22}$ Sending troops to Afghanistan and Mali helped to prepare soldiers for the reality of war at home. With that combat experience, a general acceptance of the consistency of Russian meddling and aggression, and a renewed sense of responsibility to be a pillar of defense against Russia, the military has shifted its mindset from one of complacency towards the possibility of a conflict to one of preparedness and pragmatism.

\section{Obstacles to Further Implementation of anti-Russian Policy Within the EDF}

If the policy changes in the previous section are not successfully

\footnotetext{
${ }^{20}$ Defence Budget," Republic of Estonia Ministry of Defence, last modified February 12, 2018, http://www.kaitseministeerium.ee/en/objectives-activities/defence-budget

21 Jakub Palowski, "Estonia Receives Javelin Anti-Tank Missiles From the United States" Defence 24. Last modified March 22, 2016. https://www.defence24.com/estonia-receives-javelin-antitank-missiles-from-the-united-states

22 Maj. General Martin Herem, June 11, 2018.
} 
integrated, Estonia will only become weaker and incapable of defending against a Russian invasion. While there is support amongst the Estonian population for the policy changes outlined in the National Security Concept and the procurement of more advanced weapons systems, there are some systemic problems within the EDF, described in the following paragraphs, which make integrating these policies an issue. More specifically, these systemic problems can hinder the effectiveness of the policy changes which, in the event of a Russian invasion or cyber-attack, could make the policy changes irrelevant. While the obstacles listed below are not barriers to a successful policy of deterrence targeted against Russia, they must be considered by the Estonian government.

The most significant obstacle to a successful deterrence model for the Estonian military is the feeling of many Estonian citizens that state defense is not an appropriate, necessary, or viable career path. ${ }^{23}$ Many cadets may have had bad experiences during their year of conscription and some are not inclined to continue their service. Some simply want to explore opportunities of employment in other EU countries and others have committed a crime or offense that makes them ineligible for service. ${ }^{24}$

As a result of disinterest, crime, and the effects of globalization, the EDF was unable to meet its goal of 4000 military professionals by $2018 .^{25}$ The Forces are currently comprised of about 3200 professionals, up from 3000 professionals when the 2009 Long-Term Development Plan was written. ${ }^{26}$ This failure to increase the amount of military professionals is an example of a policy change by the Estonian government not being implemented successfully.

These experiences have led to a low professional military participation rate amongst the Estonian public. While motivating the population to devote their careers to state defense may be difficult, investing in socioeconomic programs to decrease wealth inequality and increasing awareness about Estonian military career options within the population could help increase the number of military professionals in the Defense Forces.

It can be concluded from these obstacles that a successful implementation

\footnotetext{
23 Maj. General Martin Herem, June 11, 2018.

24 Enno Motts (Commandant of the Estonian National Defence College), in-person interview, June 12, 2018

25 Estonian Long Term Defence Development Plan 2009-2018. Date published January 22, 2009.

26 Maj. General Martin Herem, June 11, 2018.
} 
of these policies is not guaranteed. The EDF is an extensive and intricate force which cannot be reformed overnight. Reform requires a feasible yet rigorous and meticulous assessment of the current EDF in order to succeed.

\section{Estonian Defense League (EDL)}

While the EDF is an integral part of the plan to defend against Russia, the Estonian Defense League is a military unit unique to Estonia which provides a civilian response to an attack on the country. The EDL and EDF work hand in hand to act as a credible deterrent against an enemy with a larger and far more experienced military. The EDF uses the EDL as a unit already deployed inside of what would be enemy territory if Russia invaded and as a result, the EDL can act as a guerilla force against an invading military. The EDF relies on the steadfastness and determination of Estonian civilians in the EDL who will represent the first line of defense against Russia.

\section{OVERVIEW OF THE ROLE OF THE EDL WITHIN THE ESTONIAN GOVERNMENT}

While the EDF is the government's main military force, the Estonian Defense League (EDL) is a voluntary wing of the Estonian Defense Forces which focuses on local defense and a civilian response in the event of an invasion or security threat. It is a local force which tactically supports the Estonian Defense Forces with light infantry units. The units compliment the Defense Force's heavier equipment as well as NATO tanks and jets which would operate on Estonian soil in the event of an invasion. The EDL is a strictly deterrent force and do not take part in offensive propaganda efforts in the heavily Russian eastern region of Estonia. ${ }^{27}$

\section{Policy Changes in the EDL in Response to Russian Aggression}

Following acts of Russian aggression, the EDL has expanded its role within the Estonian military apparatus and instituted a number of programs to better equip civilians with the weapons and tools necessary to fight off an attack from the East. The EDL established the Estonian Defense League Cyber Unit (EDLCU) in 2007 which works with the private sector to allow cyber companies to be called upon in the wake of a cyberattack. ${ }^{28}$ The command provides education and training and is a direct result of the findings that primarily private

27 Lieutenant Colonel Lillenrum, May 31, 2018.

28 Ingvar Pärnamäe, June 8, 2018. 
companies, not the government, were able to counter the 2007 cyberattacks. ${ }^{29}$ After Crimea in 2014 and to better prepare against a Russian hybrid invasion, the EDL now provides new $90 \mathrm{~mm}$ anti-tank guns, Carl Gustav grenade launchers, MG-3 machine guns, and Swedish AK 4 rifles to its members. ${ }^{30}$ These weapons, provided now in greater numbers than ever before, enable the EDL to more adequately fight an invading Russian force. ${ }^{31}$ The weapons are provided by the EDL and given directly to the League's members for home storage which drastically shortens the time it would take to mobilize a unit to under 24 hours. ${ }^{3233}$

These policy changes within the security apparatus of the Estonian government have been a success and the weapons and increased preparation with which the EDL now operates greatly increases the League's chance of an effective defense against Russia. The coordination and cooperation between the EDL and EDF further prove Estonia's commitment to improving their internal military apparatus, and as a result, show the NATO alliance their commitment to its defense. These successes also set an example to other NATO members on how to adapt practical policies to fight Russia.

\section{ObstaCles to SuCCESS FOR the EDL WHEN RESPONDING to RusSIAN AgGRESSION}

Similar to the Estonian Defense Forces as a whole, the Defense League faces some issues with ethnic Russians potentially fighting against their Russian brothers in the event of an invasion. This would create a conflict of interest amongst League members. However, Defense League LTC Lillenrum is confident that Russians who fight on the side of the Defense League understand the poverty on the Russian side of the border. ${ }^{34}$ There have been instances where local Estonian police have needed backup to quell pro-Russian riots in the east

29 Tom Gjelten, "Volunteer Cyber Army Emerges in Estonia." NPR. Last modified January 4, 2011. https:/www.npr.org/2011/01/04/132634099/in-estonia-volunteer-cyber-army-defendsnation

30 “Kaitseliit marsib suurimal kaitseväe paraadil," Kaitseliit, last modified February 21, 2014, http://www.kaitseliit.ee/et/kaitseliit-marsib-suurimal-kaitsevae-paraadil

31 Andrew E. Kramer, "Spooked by Russia, Tiny Estonia Trains a Nation of Insurgents." New York Times. Last modified October 31, 2016. https://www.nytimes.com/2016/11/01/world/ europe/spooked-by-russia-tiny-estonia-trains-a-nation-of-insurgents.html

32 Lieutenant Colonel Lillenrum, May 31, 2018.

33 Léo-Paul Jacob, "How can the Estonian Defence League Ensure Estonia’s Security?" NATO Association of Canada. Last modified January 20, 2017. http://natoassociation.ca/how-can-theestonian-defence-league-ensure-estonias-security/

34 Lieutenant Colonel Lillenrum, May 31, 2018. 
of Estonia. In these instances, entire ethnically Russian Defense League units came to the aid of the local ethnically Estonian police force and suppressed the uprisings. ${ }^{35}$ Therefore, despite media and outsider speculation, there is very little conflict between ethnic Russians and ethnic Estonians within the Defense League and the voluntary force remains a strong deterrence to Russian aggression. Similar to the EDF, reform in the EDL will not come easily. The lack of participation ofethnic-Russiansinthe Leaguecertainlypresentsaconcern. The League was established over a century ago, and change can be difficult. However, with an enthusiastic and determined Estonian government, these obstacles can be overcome.

\section{ESTONIA AND NATO}

\section{NATURE OF THE ESTONIA-NATO RELATIONSHIP: EXAMPLES OF ESTONIAN LEADERSHIP IN THE CYBER SPHERE AND BEYOND}

NATO is the most important global partner of the Estonian military and is the guarantor of its safety and security. NATO provides Estonia with both heavy support weaponry such as tanks and jets, but also, under Article $\mathrm{V}$ of the NATO treaty, a collective defense policy which gives Estonian officials peace of mind when dealing with Russia. The success of this relationship is critical from a perspective of Western defense against Russia.

Estonia has done as much as possible to return the favor and provide NATO with a staging ground for cyber defense. Despite only being supported by the U.S. immediately after joining the alliance in 2004, Estonia set up the NATO Cooperative Cyber Defense Centre of Excellence (CCDCOE). ${ }^{36}$ Only after the 2007-2008 cyberattacks on Estonia and Georgia did the rest of NATO alliance begin to understand the importance of the CCDCOE. Estonia also hosts the Cyber Coalition exercise on cyber security and has provided the entire NATO alliance with advanced and up-to-date cybersecurity policy to mitigate potential future threats. ${ }^{37}$

Estonia's creation of the CCDCOE of its own volition and support of cyber exercises help prove to its NATO allies both the seriousness of the cyber threat as well as Estonia's willingness to set an example as a country who stands up to the Russian bully in the east. Estonia dealt with the cyber-attacks of 2007 by making clear to the public that the aggressor was Russia. ${ }^{38}$ By calling

\footnotetext{
35 Maj. General Martin Herem, June 11, 2018.

36 Lauri Almann (Co-Founder of BHC Laboratory), in-person interview, June 1, 2018.

37 Dr. Pauli Järvenpää, Piret Pernik, Ivo Juurvee, Kalev Stoicescu, June 4, 2018.

38 Lauri Almann, June 1, 2018.
} 
out the Kremlin, the Estonian government maintained the trust between itself and its citizens. Maintaining this trust was necessary to avoid a mass panic and damaging consequences such as a bank run which can ensue during times of crisis.

Estonia has also significantly bolstered its conventional defense forces to provide stability to the NATO alliance. The expanded and improved EDF and EDL help NATO ensure that Estonia can draw out a Russian invasion long enough to maintain some sovereignty before help arrives. This effort guarantees that a hypothetical NATO mission to remove Russian soldiers from Estonian territory would have a place to anchor itself rather than being forced to dislodge a Russian occupying force in the whole of Estonia proper.

Deployments of troops to NATO missions, the establishment of programs like the CCDCOE, and the building up of the EDF, all assist NATO in the fight against Russian aggression and help contribute to the Article $\mathrm{V}$ commitment of the alliance. Overall, the relationship between NATO and Estonia is symbiotic with each providing an integral and significant part of the other's defense capabilities. This symbiotic relationship will help NATO successfully defend against a Russian attack.

\section{Evolution of NATO Policy in Estonia}

NATO's defense against Russia must run through Tallinn. Therefore, to understand how Estonia has responded to episodes of Russian aggression, the history of NATO's relationship with Estonia, Estonia's internal developments in response to NATO policy, and the overall support of NATO amongst the Estonian people must be analyzed.

Following the invasion of Crimea, NATO convened for a summit in Wales in September 2014. The goal of the summit was to reassure NATO allies, especially border states like Estonia, of NATO's commitment to their defense. President Obama even visited Tallinn days before the summit to meet with all three Baltic leaders and give them personal reassurance of the Alliance's support. ${ }^{39}$ The Wales summit produced a joint declaration condemning Russian advances into Ukraine as well as a communiqué reassuring the Baltic states that Article $\mathrm{V}$ would be invoked if any Russian troops entered a NATO member state's territory. Although much of the 2014 summit was talk rather than action, it provided NATO states the support and reassurance they needed to avoid any potential internal crisis.

39 Gregory Korte, "Obama visit to Estonia sends message to Russians," USA Today," last modified September 3, 2014. https:/www.usatoday.com/story/news/politics/2014/09/02/obamaestonia-nato-summit/14951427/ 
Twoyearslaterin Warsaw, NATO produced a morecomprehensive response to Russian actions in Crimea with three affirmations that directly affected Estonia:

Enhanced Deterrence - NATO promised to enhance deterrence by increasing the forward presence, specifically in the Eastern flank of the alliance which is only connected to the rest of the NATO European member states by the $104 \mathrm{~km}$ border between Lithuania and Poland. ${ }^{40}$

Developing Partnerships - NATO planned to develop mutually beneficial partnerships with Sweden and Finland, two non-member states. Both countries are enhanced opportunity partners and participate in NATO activities on a regular basis. They are both advanced freemarket economies, and Finland's extensive military capabilities and large shared border with Russia would strengthen the alliance's stance against the Kremlin. ${ }^{41}$

Visible Security Upgrades - NATO deployed an Enhanced Forward Presence (EFP) in the Baltics consisting of four battalion-size battle groups. ${ }^{42}$ The EFP is a visible step towards ensuring the security of the Baltic states and sends a clear message to Russia that NATO will not tolerate any Russian attack on a member state.

The 2016 Warsaw summit declaration not only turned talk into action, but showed Russia that NATO was serious about defending its members' borders. While it took the annexation of Crimea for NATO to understand the gravity of the Russian threat, Estonia is in a much safer position now than it was before the Warsaw Summit Communiqué. Estonia depends on NATO for protection and is projected to be one of only eight-member countries in 2018 which will

\footnotetext{
40 “Warsaw Summit Communiqué," NATO, Last modified March 29, 2017, https://www. nato.int/cps/en/natohq/official_texts_133169.htm

41 Christopher S. Chivvis, "Sweden, Finland, and NATO," The German Marshall Fund of the United States, last modified June 30, 2017. Sweden, Finland, and NATO.” http://www.gmfus. or g/publications/sweden-finland-and-nato

42 "Warsaw Summit Communiqué," NATO.
} 
meet NATO's requirement to spend 2\% of GDP on defense. ${ }^{43}$ Estonians are proud they do their part; the NATO alliance and its strong, determined response during the Warsaw summit reassured the Estonian government of its security. NATO policy towards Estonia and Estonia's policy towards the alliance have been extremely successful. Estonia has taken initiative to establish programs and be a leader in the fight against Russian aggression. They have also promised to spend the required $2 \%$ of GDP on defense which secures praise from more powerful members of the alliance such as the U.S. These programs and policy changes established during NATO summits have strengthened the NATO alliance and helped Estonian society live without fear of an attack.

While the Estonia-NATO fight against Russian aggression has been successful, there has been a significant lack of motivation amongst other NATO member states who have a more intimate relationship with Russia. The reluctance of many NATO member states to spend 2\% of GDP represents a major concern for the alliance. Estonia should continue to push its NATO allies to increase their defense spending by being the example.

\section{Estonia AND THE EUROPEAN UNION}

\section{NATURE OF THE ESTONIAN-EU RELATIONSHIP}

Estonia joined the EU in 2004. Although being less direct in its defense policy requirements for member states, the EU recommends actions for member states to undertake to ensure their protection. Similar to the actions of the Estonian government within the NATO alliance, Estonia has been prominent in promoting EU security policy against Russia and in using EU resources to combat disinformation campaigns. Through its membership in the $\mathrm{EU}$, Estonia can help change policy to better align with its anti-Russian views.

\section{EAST STRATCOM TASK FORCE}

Founded in 2015, The East StratCom Task Force aims to promote EU policies in the Eastern Partnership Countries, strengthening the media environment in the East, and improve the capacity to respond to, address, and forecast

43 Martin Banks, "Results are in: Here's how much NATO allies spent on defense in 2017,” DefenseNews, last modified March 15, 2018. https://www.defensenews.com/global/ europe/2018/03/15/results-are-in-heres-how-much-nato-allies-spent-on-defense-in-2017/ 
disinformation campaigns. ${ }^{445}$ To improve the media environment, Estonia has reinforced the media environment goals of the Task Force when it comes to the Estonian media environment by launching launched the Russian -language Estonian television channel ETV+ in 2015 as a way to challenge traditional Russian -language media from Moscow. ${ }^{46}$ The Task Force produces a weekly disinformation review further enabling Estonia to respond to tactics and strategies employed by the Kremlin to cause chaos in the West. This review analyzes news coming from Moscow and verifies facts to ensure its credibility and the accuracy.

While focusing on the Eastern Partnership countries, the Task Force still requires cooperation from the rest of the EU that can be hard to come by as many EU states have minimal experience with the effects of disinformation campaigns and are not mandated, only suggested, to act against Russian fake news. Estonia, supported by Latvia, Denmark, and Finland, has called for permanent funding of the Task Force, but the majority of member states have not been as supportive. ${ }^{47}$ Comprised of only 14 staff members, size is a challenge for the Task Force as it aims to counter Russian media propaganda, a campaign that gave the governmentbacked company "RT" a $\$ 19$ million funding boost between 2016-2018. ${ }^{48}$

Due to the Task Force, Estonia has become a top EU fighter of Russian disinformation. However, similar European Union efforts in North Africa and the West Balkans have resulted in no substantial opponent to disinformation campaigns. ${ }^{49}$ Estonia stands by its commitment to deterrence and has zero counter-offensive propaganda campaigns on Russian soil. ${ }^{50}$ Estonia, as one of the

44 A European Union initiative to cooperate with the countries of Armenia, Azerbaijan, Belarus, Georgia, Moldova, and Ukraine

45 "Questions and Answers about the East StratCom Task Force," European Union External Action. Last modified November 8, 2017, https://eeas.europa.eu/headquarters/headquartershomepage/2116/-questions-and-answers-about-the-east-

46 Rachel Nielsen, "Estonian Launches New Channel to Win Over Its Russians," The Moscow

Times. Last modified September 27, 2015. https://themoscowtimes.com/articles/estonialaunches-new-channel-to-win-over-its-russians- 49854

47 "Estonia calls for permanent funding for task force countering Kremlin propaganda," Estonia Public Broadcasting. Last modified October 22, 2016, https://news.err.ee/119464/estonia-callsfor-permanent-funding-for-task-force-countering-kremlin-propaganda

48 "Kremlin Boosts Budget for TV Channel RT," The Moscow Times. Last modified December 1, 2016, https://themoscowtimes.com/news/rt-channel-gets-additional-12-bln-rubles-56375

49 Representative from Estonian Foreign Ministry, in-person interview, June 13, 2018.

50 "Questions and Answers about the East StratCom Task Force," European Union External Action. 
smaller member states in population, GDP, and area, proudly holds its own when combating disinformation. Overall, the EU as a whole has failed to understand, predict, and thwart Russian disinformation campaigns. By continuing to lobby for assertive anti-Russian policy and by setting an example for the rest of the Union, Estonia will be able to more successfully combat Russian cyber aggression.

\section{Private InVESTMENT}

\section{The Relationship between the Estonian Private Defense Sector and the ESTONIAN GOVERNMENT}

Estonia's anti-disinformation relationship with the EU and NATO are important, but without proper support from the private defense sector in Estonia, the expanded relationship of Estonia and NATO/EU will be for not. The EU and NATO provide support to the Estonian government rather than a continued presence advising and aiding the military. The Estonian Ministry of Defense must then use all of its available partnerships to improve upon its own security capabilities and to adequately defend against a Russian threat. Private companies who develop military weapons and cyber hardware are capable of inventing more efficient and effective tools than the Estonian government. Harnessing the success and innovation of the Estonian private sector can help bolster a military who must focus the majority of its spending on training and upkeep and enable a more successful and credible deterrent force against Russia.

\section{Evolution of Estonian Government Policy towards the Private Sector}

While private contractors and private investment have become a more integral part of Estonia's military-industrial complex, there was no specific Russian attack that caused the drastic change in private investment in Estonian defense companies. Instead, there has been a slow and steady increase in the amount of private contracting with the Estonian military, which has enabled the country to be better prepared in the private and government sectors in the event of a Russian attack. This steady increase has been the result of the continued growth of the Estonian economy and its further integration with the EU. By increasing the domestic production of military hardware, the EDF can become less reliant on their NATO allies for weapon systems support and can focus on the personal and professional development of their soldiers. Specifically, the Estonian government has focused on developing marketready military hardware and software. The government has also supported 
amendments which would provide the legal framework necessary for Estonian defense industry businesses to manufacture, handle, and sell heavy military equipment and the profits from these sales would then be reinvested back into the Estonian military. ${ }^{515253}$ While the Estonian government is not in the market for heavy military systems, passing these amendments would open up the Estonian defense industry to more business with allied nations and profits which would provide opportunities for foreign direct investment, jobs for Estonian citizens, and growth in the economy. ${ }^{54}$ Through an increase in private investment, the Estonian government is bettering itself as much as possible without relying on NATO or the EU for support. While this increased support will lead to a more successful defense against Russia, the private sector has yet to have a significant impact on the Estonian Defense apparatus. When the private sector does sufficiently grow to fully compliment the EDF, Estonia will be a more secure society.

\section{Overall Successes of Estonian Policy Changes towards the EDF, NATO, EU, and Private Sector}

The success of these relationships is necessary for the safety and security of the Estonian state, and without them, the peace that has permeated the European continent since the fall of the Soviet Union is once again under threat from Russia. Furthermore, the Estonian military has gone beyond its partnered government institutions with and is attempting to prepare for the future through public-private sector relationships that many developed countries rely on.

Strategically, the EDF has drastically toughed its rhetoric and changed its military policy from one of potential cooperation with Russia to one of defending Estonia from Russian cyber and conventional attacks with the aid of NATO. The international community followed suit after the 2014 Russian invasion of Crimea, and today, there exists a unified and strong anti-Russia sentiment amongst NATO member states. The placement of the battalion-sized battlegroups as well as the

\footnotetext{
51 "Committee Oks bill allowing defense industry to handle military weapons," Estonia Public Broadcasting. Last modified April 16, 2018, https://news.err.ee/820411/committee-oks-billallowing-defense-industry-to-handle-military-weapons

52 “Technology Focus Drives Estonian Defense Industry Growth," DefenseNews. Last modified November 10, 2016. https://news.err.ee/820411/committee-oks-bill-allowing-defenseindustry-to-handle-military-weapons

53 Ingvar Pärnamäe, June 8, 2018.

54 “Technology Focus Drives Estonian Defense Industry Growth," DefenseNews.
} 
establishment of multiple cyber-defense organizations in Estonia have strengthened both the Estonian defense community and NATO as a whole. Furthermore, the strategic spending of defense funds and the continuation and expansion of Estonian anti-disinformation efforts have all been important successes of the Estonian defense community. The domestic growth of Estonia's military capabilities helps the NATO alliance be more secure and confident in the Article V commitment in a time when conventional deterrence methods can be complex and incessant.

\section{Overall Deficiencies of Estonian Policy Changes Toward the EDF, NATO, EU, and Private Sector}

The lack of growth within the Estonian military defense community is the biggest outright failure of Estonian military policy in its response to Russian aggression. The number of military professionals in Estonia grew only from 3000 to 3200 between 2009 and 2018, thus failing to meet the goal of 4000 set by the nation's 2009 Long-Term Development Plan. The culprits behind this minimal growth are the lack of desire in Estonians to defend their state and the opportunity to find other career paths in other EU member states. There is also a lack of participation in the Defense League by the ethnic Russian minority which could create a divisive environment in Estonian society. While many Estonian officials believe the poverty on the Russian side of the border mitigates this conflict, the Kremlin has proven through the Bronze Horseman attacks that they are capable of taking advantage of the discontent amongst the minority.

Within NATO, and more specifically, the EU, there is hesitation on the part of other European powers to acknowledge the extent of the Russian disinformation and hybrid warfare threat. Estonia remains one of the few NATO countries spending the required 2 percent of GDP on defense. Within the EU, Tallinn continues to be the main combatant to disinformation campaigns due to the East StratCom Task Force. While there has been more commitment by EU countries to fight against Russian disinformation campaigns following Crimea in 2014, there is still not enough funding for the Task Force, whose funding is continually dwarfed by the $€ 1.2$ billion spent by Russia on information warfare.

\section{Evaluation of the Net Change of the Estonian Response to Russian Aggression}

While it can be difficult to determine the exact net change in effectiveness of the Estonian, NATO, EU, and private defense policies in regard to Russian 
aggression, it cannot be denied that the Estonian government has taken significant steps to improve the military's preparedness, strength, and cooperation with allies to combat the threat of Russian invasion. The government has taken these steps to prove to the world that it is serious about defending its sovereignty and to prove to Russia that an invasion of Estonia would be costly and detrimental to Russian interests.

The Estonian military has evolved to be leaps and bounds ahead of where it was in 2007 before the Bronze Horseman incident and subsequent cyberattacks. Before 2007, the honeymoon phase following Estonia's admission to NATO and EU contentment with the status quo led conscripts to train with little motivation or seriousness. The 2007 incidents forced the government to evolve and adapt to the changing times. The EDF has created comprehensive development plans that adequately fund vital systems to create a deterrent force in Estonia and the EDL now has significantly more weapons training than it did in 2007 for the purposes of fighting off a hybrid warfare attack by Russia. Moreover, the private investment of the Estonian military has had a slow yet steady climb, enabling private industry to adequately complement the EDF.

Cyber defense in Estonia has also evolved to be more effective than it was before 2007. The establishment of the CCDCOE in Tallinn as well as the EDLCU teaching private citizens on offensive cyber security tactics such as phishing techniques and disinformation campaigns are all representative of significant policy changes.

EU and NATO policy have also shifted since 2007 on issues that pertain to Estonian military defense. Prior to 2007, NATO and EU policy included working with Russia to cooperate on common interests and promote a secure Russo-Europe relationship. Beginning with Georgia in 2008, and, more significantly, following Crimea in 2014, the policy has changed to one of balancing against Russia rather than accommodating it.

Overall, Estonia is in a significantly stronger and more robust position to combat a direct Russian threat today than it was in 2007 or even 2014 following Crimea. The Estonian government as a whole has changed its rhetoric towards Russia, shifting from one of a desire to cooperate and improve relations in the 2004 National Security Concept to an adversarial one in the 2010 National Security Concept, which takes a hardline stance against Russian rhetoric, policy, and military advancements. War plans have been drawn up and rehearsed with 
other Allied nations and Estonia has built up its weapons systems that-when partnered with NATO heavy weaponry-will effectively block a Russian invasion. The economy has grown enough that many Estonian leaders feel confident that ethnic Russians living in Estonia will not want to return to living in poverty. While there is no way to test Estonia's military evolution over the past decade, it is clear that any Russian incursion into Narva, the largest city in Ida-Viru county, will be met with stiff resistance from the Estonian Defense League, robust support from the Estonian Defense Forces, and a weaponized response from NATO.

\section{Future Recommendations for Estonian Defense Society}

Without Estonia's continued defense of the eastern edge of the alliance, Russia will have the opportunity to gain a geopolitical foothold in the Baltics, which would accelerate the Kremlin's plan to sow distrust amongst NATO member. My interviews made it clear that both the defense and foreign ministries of Estonia are aware of the threat that Russia poses. To this point, even a representative from the Ministry of Education was conscious of how Russian-language elementary schools can exert enormous influence when students only receive information from one side of the story. Russia has and continues to carry out cyberattacks, election meddling, and disinformation campaigns in former Soviet states and around the world. In order to counter these efforts, Estonia must continue to develop their weapons systems, cyber education, and their partnerships with other NATO membersfailing to do so would trigger Article V. Developing these systems and focusing on their own capabilities will help mitigate the potential liability that Estonia presents to the NATO alliance and will better complement a NATO advanced force in the event of conflict.

In the past decade, Estonia has been tirelessly fighting Russian aggression and disinformation. While there has been talk of wavering support for NATO and EU alliances in countries such as the United Kingdom, United States, and France, Estonia has remained committed to the alliance's continued defense of their homeland. While other European countries may feel Russia is a distant threat, Estonia is on the front lines of both a conventional and cyber conflict with Russia. The potential for conflict is real and has only magnified since 2007. While members of the Estonian government and military are confident the NATO alliance is key to peace in Tallinn, that does not mean the country can remain complacent. Russia has strategically evolved their military for modern conflict (i.e., the hybrid invasion of Ukraine), and they have continued to show the West 
their disregard for human rights and their desire to reclaim a lost hegemony.

Estonia is a unique case in the NATO alliance due to its prominent Russian minority living amongst an ethnically Estonian population. Continuing to invest in programs that peacefully integrate the ethnically Russian population into Estonian society will not only help reduce the potential for future conflict with Russia but also present a more united front against the Kremlin, who would gladly reclaim their lost territory. Furthermore, encouraging allied countries to invest in fighting disinformation campaigns and in education (to help others learn and understand the capabilities of the Russian cyber and conventional threats) will help Estonia become a more confident and stable member of NATO. Estonia has and will continue to fight Russia on all fronts and after each event of Russian aggression in the past decade, Estonia has improved, innovated, and expanded its military capability to be a convincing and effective force against the Kremlin.

\section{ACKNOWLEDGEMENTS}

This research was supported by the Institute for Global Leadership at Tufts University. I would like to thank my colleagues from Tufts University, the United States Military Academy, and United States Naval Academy-in particular, Commander David Ostwind and Captain Ben Sylvester-who provided insight and expertise while conducting research in Estonia and after we returned home. I would also like to thank Noah Rose, Anna Kim, Zoe Leaf, and Rhonda Berlin for their help in the editing process. 


\section{BIBLIOGRAPHY}

"Air Force." Estonian Defence Forces. Accessed July 9, 2018. http://www.mil.ee/en/ air_force

Banks, Martin. "Results are in: Here's how much NATO allies spent on defense in 2017." DefenseNews. Last modified March 15, 2018. https://www. defensenews.com/global/europe/2018/03/15/results-are-in-heres-howmuch-nato-allies-spent-on-defense-in-2017/

Cavegn, Dario. "Majority of Estonia’s Russian-speaking Residents against NATO Presence." Estonia Public Broadcasting. Last modified June 10, 2017. https://news.err.ee/601288/majority-of-estonia-s-russian-speakingresidents-against-nato-presence

Chivvis, Christopher S. "Sweden, Finland, and NATO." The German Marshall Fund of the United States. Last modified June 30, 2017. http://www.gmfus. org/publications/sweden-finland-and-nato.

"Committee Oks bill allowing defense industry to handle military weapons." Estonia Public Broadcasting. Last Modified April 16, 2018. https://news. err.ee/820411/committee-oks-bill-allowing-defense-industry-to-handlemilitary-weapons

"Defence Budget." Republic of Estonia Ministry of Defence. Last modified February 12, 2018. http://www.kaitseministeerium.ee/en/objectives-activities/ defence-budget

"Estonia calls for permanent funding for task force countering Kremlin propaganda." Estonia Public Broadcasting. Last Modified October 22, 2016. https://news.err.ee/119464/estonia-calls-for-permanent-fundingfor-task-force-countering-kremlin-propaganda

Estonian Long Term Defence Development Plan 2009-2018. European Councilon Foreign Relations. January 22, 2009. http://www.ecfr.eu/page/-/ Estonie_-_2009_-_Estonia_long_term_development_plan_2009_2018. pdf 
“Estonia Population 2018." World Population Review. Last Modified June 12, 2018. http://worldpopulationreview.com/countries/estonia-population/

"Estonia." The World Factbook. Langley, Virginia: Central Intelligence Agency. Last Modified June 20, 2018. https://www.cia.gov/library/publications/ the-world-factbook/geos/en.html

"Exercise Siil 2018 kicks off in Estonia." North Atlantic Treaty Organization. Last modified May 8, 2018. https://www.nato.int/cps/su/natohq/ news_154275.htm

Gjelten, Tom. "Volunteer Cyber Army Emerges in Estonia" NPR. Last modified January 4, 2011. https://www.npr.org/2011/01/04/132634099/inestonia-volunteer-cyber-army-defends-nation

Jacob, Léo-Paul. "How can the Estonian Defence League Ensure Estonia's Security?” NATO Association of Canada. Last modified January 20, 2017. http://natoassociation.ca/how-can-the-estonian-defence-league-ensureestonias-security/

"Kaitseliit marsib suurimal kaitseväe paraadil.” Kaitseliit. Last modified February 21, 2014. http://www.kaitseliit.ee/et/kaitseliit-marsib-suurimalkaitsevae-paraadil

Kofman, Michael. "The Expensive Pretzel Logic of Deterring Russia by Denial." War on the Rocks. Last Modified June 23, 2016. https:// warontherocks.com/2016/06/the-expensive-pretzel-logic-of-deterringrussia-by-denial/

Korte, Gregory. “Obama visit to Estonia sends message to Russians.” USA Today. Last modified September 3, 2014. https://www.usatoday.com/story/ news/politics/2014/09/02/obama-estonia-nato-summit/14951427/

Kramer, Andrew E. "Spooked by Russia, Tiny Estonia Trains a Nation of 
Insurgents." New York Times. Last modified October 31, 2016. https://www. nytimes.com/2016/11/01/world/europe/spooked-by-russia-tiny-estoniatrains-a-nation-of-insurgents.html

"Kremlin Boosts Budget for TV Channel RT." The Moscow Times. Last Modified December 1, 2016. https://themoscowtimes.com/news/rt-channel-getsadditional-12-bln-rubles-56375

National Defence Development Plan 2018-2022. Estonian Ministry of Defence. http://www.kaitseministeerium.ee/riigikaitse2022/riigikaitse-arengukava/ index-en.html

National Security Concept of the Republic of Estonia (2004). Center for Security Studies. Date accessed July 9, 2018. https://www.files.ethz.ch/isn/156841/ Estonia-2004.pdf

“Navy." Estonian Defense Forces. Accessed July 9, 2018. http://www.mil.ee/en/navy

Nielsen, Rachel. "Estonian Launches New Channel to Win Over Its Russians." The Moscow Times. Last Modified September 27, 2015. https:// themoscowtimes.com/articles/estonia-launches-new-channel-to-win-overits-russians- 49854

Palowski, Jakub. "Estonia Receives Javelin Anti-Tank Missiles From the United States." Defence 24. Last modified March 22, 2016. https://www.defence24. com/estonia-receives-javelin-anti-tank-missiles-from-the-united-states

Parshukov, Vitalii. "Media, Memory, and Minority: The Russian-Language TV Channel ETV+ and its Role in the Long-Lasting 'War of Memories' in Estonia.” Master's thesis, University of Tartu, 2017.

"Population By Sex, Ethnic Nationality And County, 1 January." Statistics Estonia 2018. Last updated June 9, 2017. Retrieved July 16, 2018.

"Questions and Answers about the East StratCom Task Force." European Union External Action. Last Modified November 8, 2017. https://eeas.europa.eu/ 
headquarters/headquarters-homepage/2116/-questions-and-answersabout-the-east-

“Technology Focus Drives Estonian Defense Industry Growth.” DefenseNews. Last Modified November 10, 2016. https://news.err.ee/820411/ committee-oks-bill-allowing-defense-industry-to-handle-militaryweapons

"Warsaw Summit Communiqué." NATO. Last modified March 29, 2017. https://www.nato.int/cps/en/natohq/official_texts_133169.htm 